\title{
GPSブイ式波浪計を対象とした複合的な 波向き計算手法の改良
}

AN IMPROVEMENT OF DIRECTIONAL WAVE DATA ANALYSIS PROCEDURE FOR THE GPS BUOY

\author{
清水勝義 1 橋本典明 2 ・岩崎峯夫 3 ・安立重昭 4 ・額田恭史 5 \\ Katsuyoshi SIMIZU, Noriaki HASHIMOTO, Mineo IWASAKI, Shigeaki ADACHI \\ and Kyousi NUKADA
}

1正会員 (独)港空研 海洋・水工部海象情報研究室長（广T239-0826 神奈川県横須賀市長瀬3-1-1）

2フェロー 工博 九州大学大学院 工学研究院 環境都市部門 沿岸域環境学講座 教授

( $\overline{1} 819-0395$ 福岡市西区元岡 744)

3正会員 工修 (社)海洋調査協会 専務理事（テ103-0023 東京都中央区日本橋本町2-8-6)

4正会員 工修 (株)カイジョーソニック 理事 (T190-1222 東京都西多摩郡瑞穂町箱根ヶ崎東松原19-6)

5 工修 (株)エコー (テ 110-0014 東京都台東区北上野2-6-4)

The GPS buoy can measure the coordinates of the vertical and horizontal position of the receiver equipped at the top of the buoy by the RTK-GPS method to an accuracy of centimeter every second. In the previous paper, we proposed a method for estimating the representative wave direction from the GPS information. In the method, first, the observed time series data were separated into components, then, the predominant direction is derived from the horizontal displacement having the maximum power, and finally the representative wave direction is determined with reference to the sign of the covariance value between the vertical displacement and horizontal velocity. Although this method can estimate wave direction in the full range of 360 degree, it has drawback in its computation time. In this paper, we therefore proposed a more efficient method in which the above numerical operations are carried out in frequency domain without applying inverse FFT. We applied this method to the observed data and discussed ils adequacy and applicability.

Key Words : GPS buoy, covariance, wave gauge, numerical filtering, wave direction

\section{1.はじめに}

GPSブイ式波浪計が，水粒子運動に必ずしも追従 しないため ${ }^{1)}$ ，複合的波向き計算の手法が提案さ れている ${ }^{2)}$ 。これは, 観測データを周波数帯別に 分離し, 各周波数帯のブイの水平位置データからパ ワーが最大となる方向を算出し，その方向における 水平速度データと垂直位置の共分散を計算し，共分 散值の符号を波向の符号とし，360度で定義される 波向きを求める手法である。

現在, 日本の沿岸の配置されている海象計及び GPS ブイ式没浪計データは，集中処理されて，海象 情報は，リアルタイムに発信されている。このよう な，システム環境では，できる限り高速な波向き計 算手法が要求される.

そこで，本研究では，逆 FFT 演算を全く行うこと なく，時系列デー夕を用いて行われているパワーが 最大となる方向を求める計算と共分散計算とを，周 波数ドメインで計算し，この複合的波向き計算法の 高速化を行った。さらに，この波向き計算手法の妥 当性について, 高波浪時における実際の観測データ を元に検証を行った.

\section{2. 改良した複合的波向き計算手法}

（1）実波浪計ブイの位相の周波数応答

波向き計測は，位相のずれを基に語测する。そこ で，東北地方整備局の宮城県中部沖のGPSブイ式波 浪計の実データを用いて，スペクトル解析を行い， 位相のずれを調べた。

南北方向

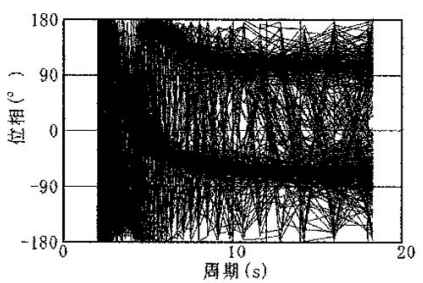

図-1 宮城県中部沖GPSブイの位相応答特性

図-1に波高 $\left(\mathrm{H}_{1 / 3}\right)>3 \mathrm{~m}$ 場合のデータから得られ たブイ垂直位置とブイ水平位置の位相の周波数応答 特性を示す。この図から分かるように，周期5秒以 下の領域では，位相ずれが十または一90度から離れ る現象が見られる。また，周期10秒以上の領域でも， 
位相の值は，一定値に近くなるが，幅をもち必ずし も90度になっていないことが分かる。これらは，単 純な共分散計算で波向きを求めることが難しいこと を示している。

\section{（2）180度波向きの計算}

主波向きは, 次の手法で計算できる. ブイの水平 移動動摇の中心を中心をする座標で，ブイの位置 $\left(X_{\mathrm{i}}, Y_{\mathrm{i}}\right)$ がn個の時系列データで示されているとす る.このブイの位置データ $\left(X_{\mathrm{i}}, Y_{\mathrm{i}}\right)$ は，ディジタ ルィルター等で, ある周波数帯域に制限された場合 の位置であっでよい，

このとき，2次モーメント（パワー）が最大にな る方向を波向きの方向とする. 具体的には, 元のX, Y座標から佪転した座標上のX軸方向の2次モーメ ントが最大となれば，そのX軸方向が主波向の方向 となる ${ }^{3)}$.

回転角 $\theta$ 回転した座標のX軸方向の 2 次モーメント $M_{X X}(\theta)$ は，次式で表される.

$$
M_{X X}(\theta)=\sum_{i=1}^{n} X_{i}^{2}(\theta)
$$

ただし， $X_{i}(\theta)$ は， $\theta$ 回転した座標でのX座標值であ る。

式(1) は，座標変換しない元の座標すなわち，0度 回転した座標の $X, Y$ 座標值 $X(0), Y(0)$ を用いた，座標 変換の式(2)を用いて，式(3)で表される

$$
\begin{aligned}
X_{i}(\theta)= & X_{i}(0) \cos (\theta)+Y_{i}(0) \sin (\theta) \\
M_{X X}(\theta)= & \cos ^{2}(\theta) \cdot M_{X X}(0)+\sin ^{2}(\theta) \cdot M_{Y Y}(0) \\
& +2 \cdot \cos (\theta) \cdot \sin (\theta) \cdot M_{X Y}(0)
\end{aligned}
$$

2次モ一メント $M_{X X}(\theta)$ が最大（極大），最小（極

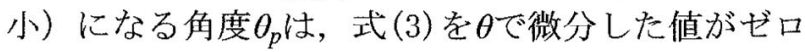
となる条件を用いて式(4)夯得られる.

$$
\theta_{\mathrm{P}}=\frac{1}{2} \tan ^{-1}\left(\frac{2 M_{X Y}(0)}{M_{X X}(0)-M_{Y X}(0)}\right)
$$

ただし，

$$
\begin{aligned}
M_{X X}(0) & =\sum_{i=1}^{n} X_{i}^{2}(0), \quad M_{Y Y}(0)=\sum_{i=1}^{n} Y_{i}^{2}(0), \\
M_{X Y}(0) & =\sum_{i=1}^{n}\left\{X_{i}(0) \cdot Y_{i}(0)\right\}
\end{aligned}
$$

である。

角度 $\theta_{\mathrm{p}}$ がモーメント最大の方向か, 最小になる方 向か不明なため，式(3)をさらに $\theta$ で微分し， $\theta$ に $\theta_{\mathrm{p}}$ を代入すると式(5)が得られる.

この值Aが正なら，モーメント最小の方向を，負 なら最大の方向を示寸.したがって, 正の場合は,
90度異なる方向になる。その結果，モーメント最大 の角度を $\theta_{\max }$ とすると式(6)で表される.

$$
\begin{aligned}
& \mathrm{A}=-2 \cos 2 \theta_{p} \cdot\left(M_{X X}(0)-M_{Y Y}(0)\right) \\
& \quad-4 \sin 2 \theta_{p} \cdot M_{X Y}(0) \\
& \theta_{\text {max }}=\theta_{\mathrm{P}} \quad(\mathrm{A}<0), \\
& \theta_{\text {max }}=\theta_{\mathrm{P}} \pm 90 \text { 度 } \quad(\mathrm{A}>0)
\end{aligned}
$$

\section{（3）360度波向きの計算理論}

式 (6) で示される $\theta_{\max }$ 方向は, 波の振動方向で, 波の進行方向を必ずしも示さない，波向きは, 波高 が高いときの水粒子の進行方向であるため, 高さ方 向の位置Zの情報を用いて, 進行方向を定めことが できる.すなわち， $\theta_{\max }$ 方向の次の共分散值を用い て判断することができる.

理論的に, $\mathrm{x}, \mathrm{y}$ 方向の位置と $\mathrm{z}$ 方向の位置は, 位 相が90度異なっているため, 共分散值は, 何孔の場 合も0となり，位相の違いを検出できない。このた め, 垂直か水平変位のどちらかの変位を 90 度位相を ずらす必要がある。このため，一般の波向計は，水 平位置を微分して 90 度ずらした值になる水平流速と 垂直変位の共分散計算が行われる。

ここでは，垂直位置Zの位相を90度遅らすことに する．垂直位置Zの位相を90度遅らせたものをZ すると。

回転角 $\theta_{\max }$ 回転した座標の $\mathrm{x}$ 軸力向上での 90 度位 相遅らせた垂直変位 $\mathrm{Z}_{-90}$ と水平変位 $\mathrm{X}$ の共分散 $M_{-90 Z X}\left(\theta_{\max }\right)$ は, 式(7)で示される.

$$
M_{-90 Z X}\left(\theta_{\max }\right)=\sum_{i=1}^{n} Z_{-90 i} X_{i}\left(\theta_{\max }\right)
$$

式(7)に式(2)を代入すると，

$$
\begin{aligned}
& M_{-90 Z X}\left(\theta_{\max }\right)=\sum_{i=1}^{n} Z_{-90 i} X_{i}\left(\theta_{\max }\right) \\
& =\cos \left(\theta_{\max }\right) \cdot \sum_{i=1}^{n} Z_{-90 i} X_{i}(0)+\sin \left(\theta_{\max }\right) \cdot \sum_{i=1}^{n} Z_{-90 i} Y_{i}(0) \\
& =\cos \left(\theta_{\max }\right) \cdot M_{-90 Z X}(0)+\sin \left(\theta_{\max }\right) \cdot M_{-90 Z Y}(0)
\end{aligned}
$$

したがって，360度波向き（進行方向）を $\phi$ とする 々, 次式(8)で示される.

$$
\begin{aligned}
& \phi=\theta_{\max } \quad\left(M_{-90 Z X}\left(\theta_{\max }\right)>0\right), \\
& \phi=\theta_{\max } \pm 180 \text { 度 } \quad\left(M_{-90 Z X}\left(\theta_{\max }\right)<0\right)
\end{aligned}
$$

\section{（4）位相90度遅らす計算}

周波数領域では, 時系列デー夕が, 複素正弦状波 の和で表される。このため,この正弦状波の複素振 幅を 90 度位相遅らせばよい。複素振幅 $\mathrm{A}$ と位相 -90 度遅れた複素振幅は，位相をずらす伝達関数を乗じ て，式(9)で示される。ただし，jは，虚数でjを掛け ると 90 度位相進み，一jを掛けると90度遅れる。 


$$
\begin{aligned}
& B \cdot e^{j \omega t}=(b-a j) \cdot e^{j \omega t} \\
& =-j(a+b j) \cdot e^{j \omega t}=-j A \cdot e^{j \omega t}
\end{aligned}
$$

\section{（5） 周波数領域でのパワーの計算}

複素フーリ工係数を求めるFFTプログラムは，時 系列デ一タを, 複菜正弦状波 $C \mathrm{e}^{\mathrm{j \omega t}}$ とその共役複素 正弦状波 $C^{*} \mathrm{e}^{-\mathrm{j} \omega \mathrm{t}}(\omega=0 \sim \pi / \mathrm{dt})$ の)和に分解する。 ただし，C゙は，Cの共役複素数である。

ここで，Cは，複素振幅と呼ばれる，得られた複 素振幅を $C\left(f_{\mathrm{i}}\right)$ とすると，式(10)が成立する。ただし， 周波数 $f_{\mathrm{i}}$ は $f_{\mathrm{i}}=\mathrm{i} / \mathrm{n} / \mathrm{dt}(\mathrm{Hz})(\mathrm{i}=0, \cdots \cdots, \mathrm{n} / 2)$ で， $\mathrm{n}$ は データ数で, dt はサンプリング時間閒隔で, Pは全 パワーを示す.

$$
\begin{aligned}
& P=\frac{1}{n} \sum_{i=1}^{n} X_{i}^{2} \\
& =\left|C\left(f_{0}\right)\right|^{2}+2 \cdot \sum_{i=1}^{n / 2-1}\left|C\left(f_{i}\right)\right|^{2}+\left|C\left(f_{n / 2}\right)\right|^{2}
\end{aligned}
$$

ただし，

$$
\begin{array}{ll}
C\left(f_{i}\right)=\mathrm{a}_{\mathrm{i}}+\mathrm{b}_{\mathrm{i}} j & \text { で表されると, } \\
\left|C\left(f_{i}\right)\right|=\sqrt{\mathrm{a}_{\mathrm{i}}^{2}+\mathrm{b}_{\mathrm{i}}^{2}}, & \left|C\left(f_{\mathrm{i}}\right)\right|^{2}=\mathrm{a}_{\mathrm{i}}^{2}+\mathrm{b}_{\mathrm{i}}^{2}
\end{array}
$$

である。

したがって，ある周波数帯 $\mathrm{i}=1 \sim \mathrm{m} の 2$ 次モーメン ト $M_{x x}(0)$ と $M_{y y}(0)$ は, 次式で表される.

$$
\begin{aligned}
& M_{x x}(0)=2 \cdot \sum_{i=l}^{m}\left|C_{x}\left(f_{i}\right)\right|^{2} \\
& M_{y y}(0)=2 \cdot \sum_{i=l}^{m}\left|C_{y}\left(f_{i}\right)\right|^{2}
\end{aligned}
$$

\section{（6）周波数領域での共分散の計算}

複素フーリエ係数を求めるFFTプログラムで得ら れた複素振幅で，データ $\mathrm{X}_{\mathrm{i}}$ から得られたものを $C_{\mathrm{x}}\left(\mathrm{f}_{\mathrm{i}}\right)$ とし，データ $\mathrm{Y}_{\mathrm{i}}$ から得られたものを $\mathrm{C}_{\mathrm{y}}\left(\mathrm{f}_{\mathrm{i}}\right)$ とすると， 式(12) が成立する。ただし，周波数 $\mathrm{f}_{\mathrm{i}}$ は， $\mathrm{f}_{\mathrm{i}}=\mathrm{i} / \mathrm{n} / \mathrm{dt}$ $(\mathrm{Hz})(\mathrm{i}=0, \cdots \cdots, \mathrm{n} / 2)$ で, $\mathrm{n}$ はデータ数で, dtはサン プリング時間間隔で，全クロスパワーをPとする。

$$
\begin{aligned}
P & =\frac{1}{n} \sum_{i=1}^{n} X_{i} \cdot Y_{i}=C_{x}\left(f_{0}\right) \cdot C_{y}\left(f_{0}\right) \\
& +\sum_{i=1}^{n / 2-1}\left(C_{x}\left(f_{i}\right) \cdot C_{y}\left(-f_{i}\right)+C_{x}\left(-f_{i}\right) \cdot C_{y}\left(f_{i}\right)\right) \\
& +C_{x}\left(f_{n / 2}\right) \cdot C_{y}\left(f_{n / 2}\right)
\end{aligned}
$$

したがって，ある周波数帯 $\mathrm{i}=1 \sim \mathrm{m}$ の共分散 $M_{X Y}(0)$, $M_{X Z}(0)\left\llcorner M_{Y Z}(0)\right.$ は, 次式で表される.

ただし, $C_{\mathrm{x}}\left(\mathrm{f}_{\mathrm{i}}\right)$ と $C_{\mathrm{y}}\left(\mathrm{f}_{\mathrm{i}}\right)$ は, 座標回転しない元の座標 での座標值の時系列 $X_{i}$, と $Y_{i}$ ら求めたものである.

$$
\begin{aligned}
& M_{X Y}(0)=\sum_{i=l}^{m}\left(C_{x}\left(f_{i}\right) \cdot C_{y}\left(-f_{i}\right)+C_{x}\left(-f_{i}\right) \cdot C_{y}\left(f_{i}\right)\right) \\
& M_{-90 Z X}(0)=\sum_{i=l}^{m}\left(C_{x}\left(f_{i}\right) \cdot C_{-90 z}\left(-f_{i}\right)+C_{x}\left(-f_{i}\right) \cdot C_{-90 z}\left(f_{i}\right)\right) \\
& M_{-90 Z Y}(0)=\sum_{i=l}^{m}\left(C_{y}\left(f_{i}\right) \cdot C_{-90 z}\left(-f_{i}\right)+C_{y}\left(-f_{i}\right) \cdot C_{-90 z}\left(f_{i}\right)\right)
\end{aligned}
$$

\section{（7）波峰長パラメータの計算}

波峰長パラメータ $\gamma$ は, 次式で示される。従って, 前述の関係式を用い孔ば，周波数ドメインで計算で きる.

$$
\gamma=\sqrt{\frac{A-B}{A+B}}
$$

ただし， $A, B$ は，次のとおりである.

$$
\begin{aligned}
& A=\left(M_{x x}(0)+M_{y y}(0)\right) \\
& B=\sqrt{\left(M_{x x}(0)-M_{y y}(0)\right)^{2}+4 M_{x y}(0)}
\end{aligned}
$$

（8）具体的計算法のフロー

計算の高速性を考えFFTで時系列を周波数領域で 表し，逆変換することなく計算する新しい波向き計 算のフローを図-2に示す.

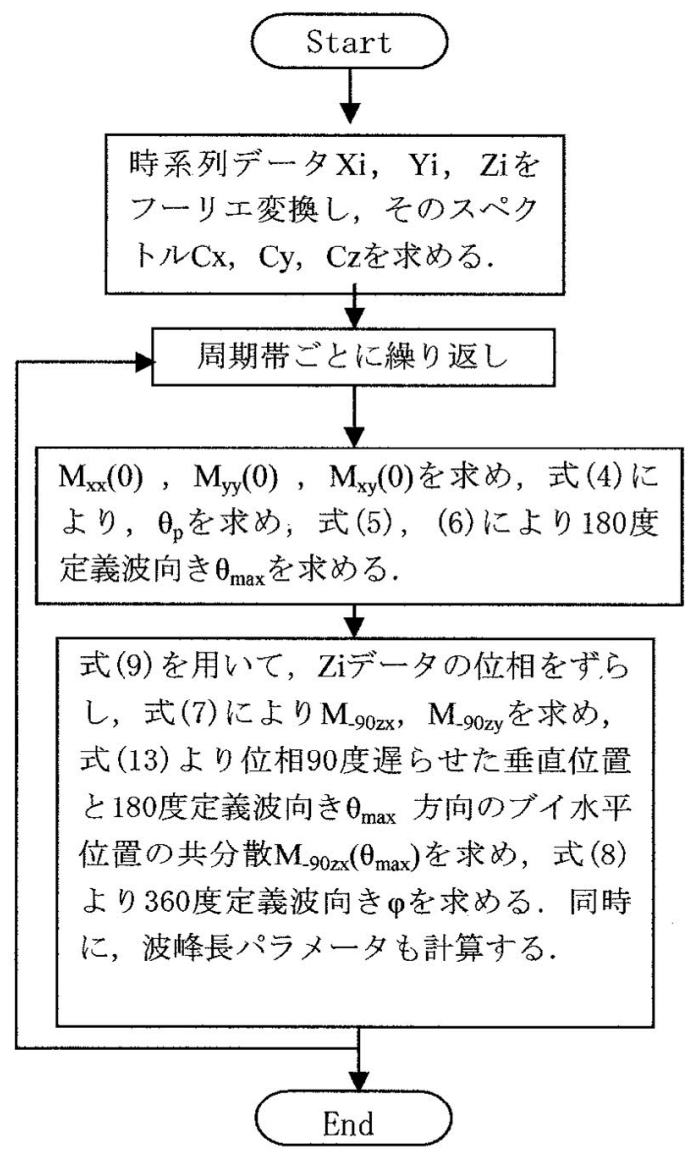

図-2 改良した手法の計算つロー 


\section{3. 観測結果への適応}

ここでは, 図-3に示す東北地方整備局の宫城県中 部沖 (水深 $144 \mathrm{~m}$ ) および岩手県南部沖 (水深 $204 \mathrm{~m}$ ) の GPSブイ式波浪計一の適応例を示す。

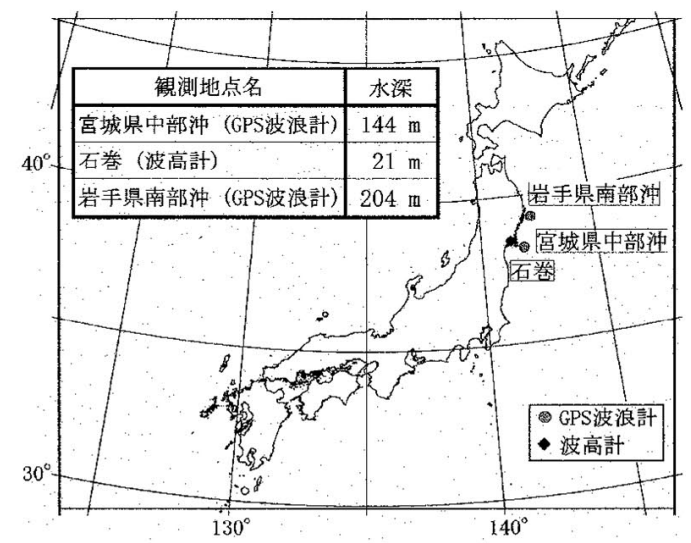

図-3 GPS ブイ式波浪計の設置位置

\section{（1）新しい手法の検証}

新しい計算手法の妥当性を調べるため，ブイの水 平位置の散布図と計算された波向きを図-4に例示す る. なお，この場合の $8 \sim 10 \mathrm{~s}$ の周期带の有義波高

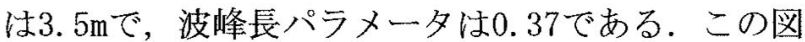
から，波の振動方向は，正しく計算されていると判 断される.

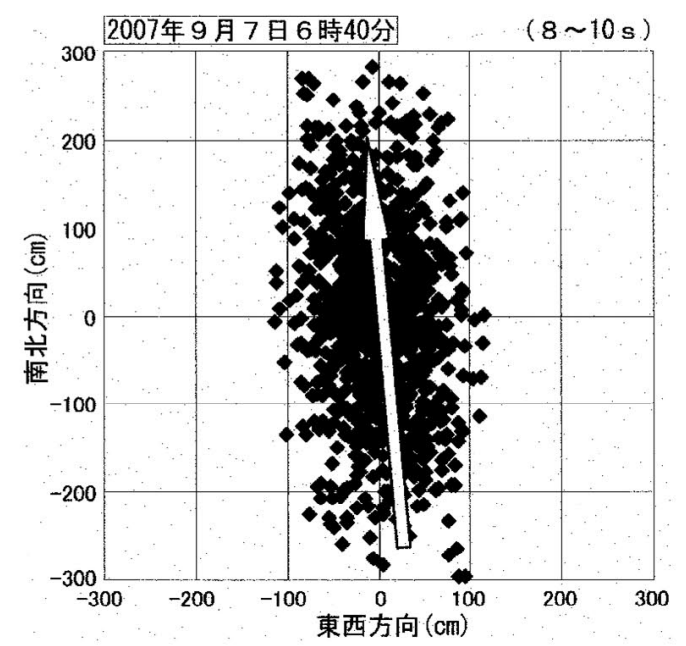

図-4 ブイ位置の散布図と波向きの計算結果

\section{（2）台風 0709 号}

図-5に台風0709号の経路を示し，図-6に台風0709 号接近時の宮城県中部沖および岩手県南部沖観測点 にお注る周波数帯別波向きの経時变化を示した。ま た，比較のために，近傍の観測地点である石巻 (海 底設置型海象計)の結果についても示した。図-6か ら，9月 7 日正午頃の高波浪時に石巻では砕波によ り波向きが観測できてないのに対し両GPSブイ式波
浪計では連続的に計測できている.

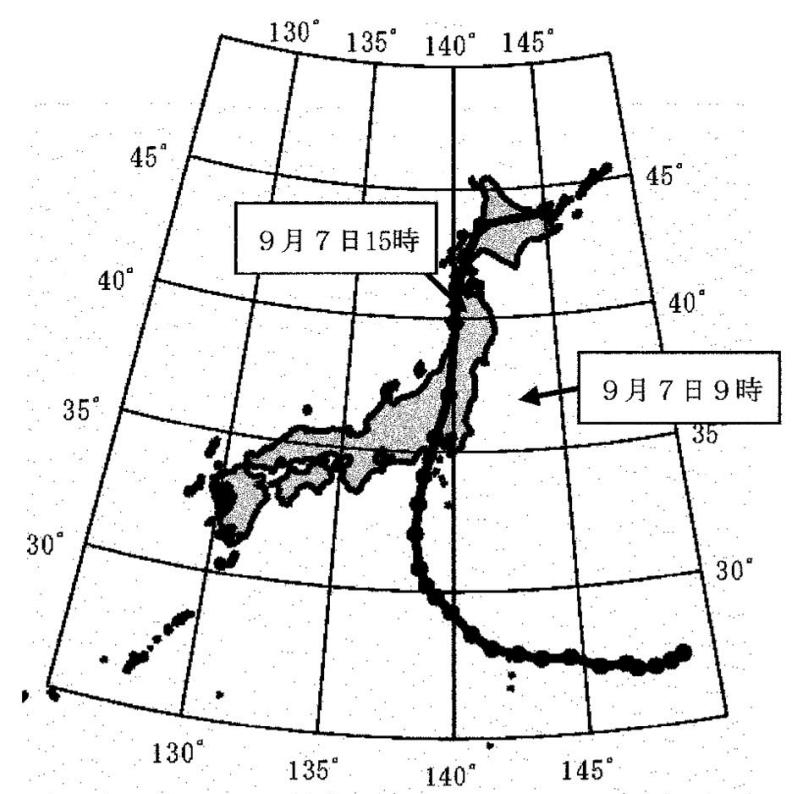

図-5 台風0709号の経路
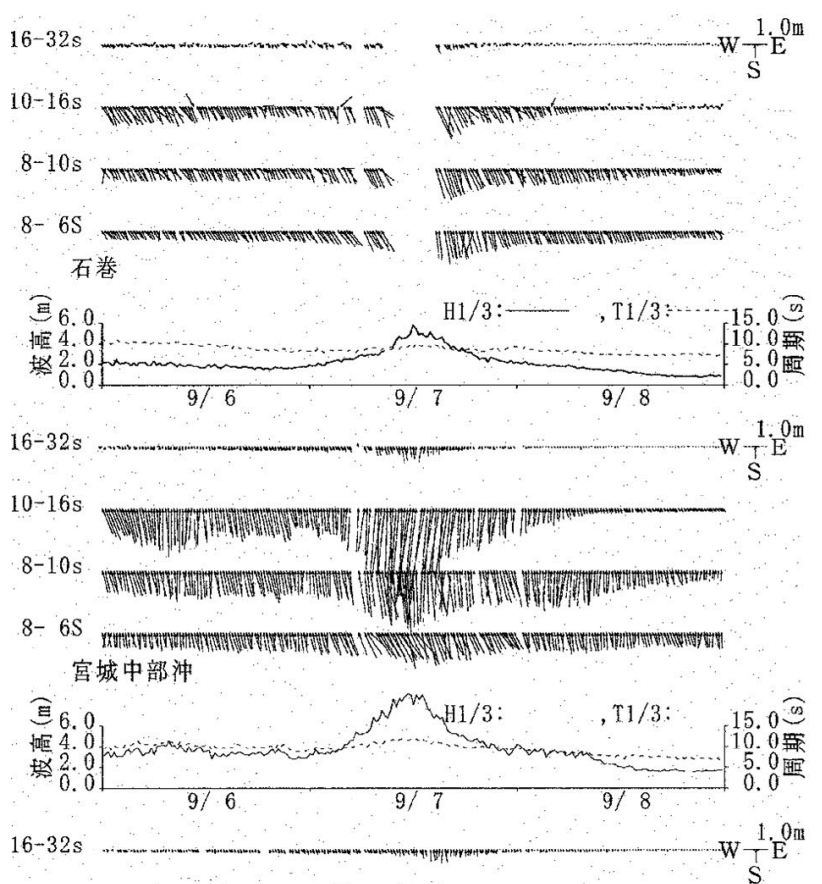

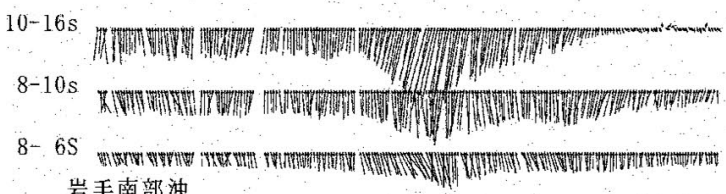

岩手南部沖

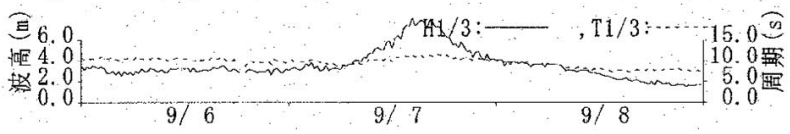

図-6 周波数帯別波浪時系列

\section{（3）方向スペクトルの形状に関する検討}

方向スペクトルのエネルギー分布幅に関する指標 としては, Longuet-Higgins が提案した波峰長パ ラメーター $\gamma$ や合田が提案した平均分散角 $\theta_{\mathrm{k}}$ 等が 
ある．小舟，橋本，佐々木らは， $\theta_{\mathrm{k}}$ と $\gamma$ の関係から 光易型方向関数の方向集中度 $\mathrm{S}_{\max }$ を推定する方法を 示し，野島崎沖海域の方向スペクトル特性を検討し ている ${ }^{4)}$. 図-7 は，小舟らの方法により $\theta_{\mathrm{k}}$ と $\gamma$ の 関係を求めをものである. 図中のの印は単峰型の方 向スペクトルでの $\theta_{\mathrm{k}}$ と $\gamma$ の関係を示している。 ま た,曲線A は有義波波高が等しいけれども波向が異 なる風波 $\left(\mathrm{S}_{\max }=10\right)$ が重なった双峰型の方向スペク トル，B は風波 $\left(\mathrm{S}_{\max }=10\right)$ と有義波波高が風波の $1 / 2$ のうねり $\left(\mathrm{S}_{\max }=100\right)$ が重なった双峰型の方向スペク トル, $\mathrm{C}$ は風波 $\left(\mathrm{S}_{\max }=10\right)$ と等しい有義波波高のう视 り $\left(S_{\max }=100\right)$ が重なった双峰型の方向スペクトルに ついて,方向差 $\theta_{\mathrm{d}}$ を $0^{\circ}$ から $180^{\circ}$ まで変化させた 場合の $\theta_{\mathrm{k}}$ 之 $\gamma$ の関係を示している。ただし，いず れの数值計算においても，各波群の有義波周期を 10 秒として計算した。

図-8 と図-9 は, ブイ運動の 3 成分の観測結果か ら求めた $\theta_{\mathrm{k}}$ と $\gamma$ の関係を示したものである。図-8

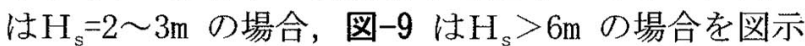
している。波高が比較的小さい $\mathrm{H}_{\mathrm{s}}=2 \sim 3 \mathrm{~m}$ の場合に は, 図中に示した $\theta_{\mathrm{k}}-\gamma$ 曲線を包絡線として, 観測值 はその右側にばらついているが，有義波高が大きく なるとそのばらつきも小さくなり, 図-7 に示した 単峰性方向スペクトルの曲線に近い範囲に集まって いる.

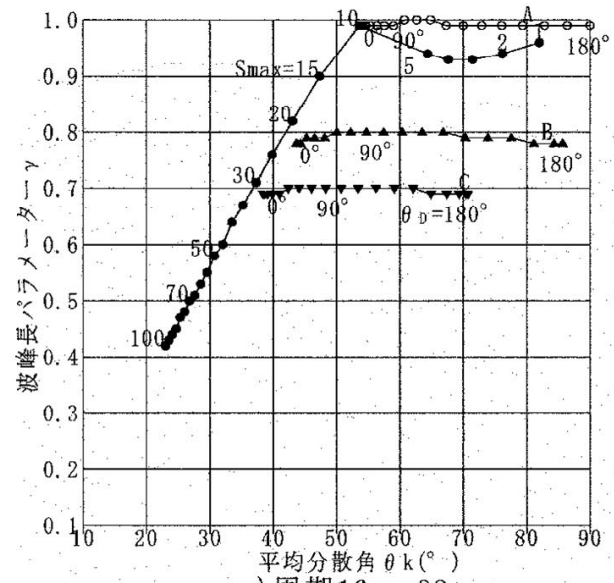

a) 周期 $16 \mathrm{~s} \sim 32 \mathrm{~s}$

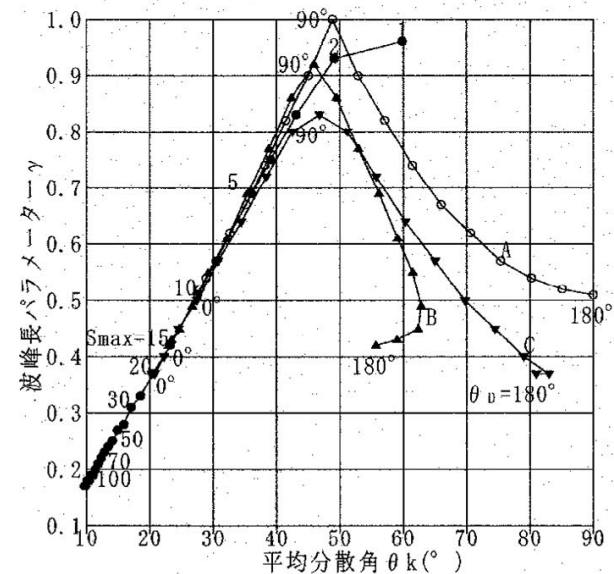

c) 周期 $8 \mathrm{~s} \sim 10 \mathrm{~s}$
最大有義波高を記録した 9 月 7 日 11 時 20 分の $\theta_{\mathrm{k}}$ と $\gamma$ の関係は, 図-9 中の印の位置にあり, 光易型 方向関数において $\mathrm{S}_{\max }=14$ に相当する.

\section{4.おわりに}

従来の手法 2) で周期帯別波向き計算を行う時, FFT でブイの位置デー夕を周波数領域で表し, 周期 帯数回の逆 FFT を行い, 各周期帯別に, ブイ位置の 時系列デー夕を求め, パワー最大の方向を求める. さらに, 周期帯ごとに, 微分演算により水平速度の 時系列データを求め, 共分散計算を求める.

この過程を高速化するため, 逆 FFT 演算と時系列 の微分演算を全く行うことなく, 同等の計算全てを 周波数ドメインで計算し，波向きを求める新しい手 法を開発した。この改良により，波向の演算時間が およそ 4 分の 1 に短縮することが出来た.

また，波向計算の高速化以外でも以下の特徴を もっている。

(1) 90 度位相をずらす部分では，微分を用いず，直 接 90 度ずらす伝達関数を用いた。このため，波向き が周期の短い方に偏ることが回避できた。

(2) 波峰長パラメータも高速に計算でき，1つの波

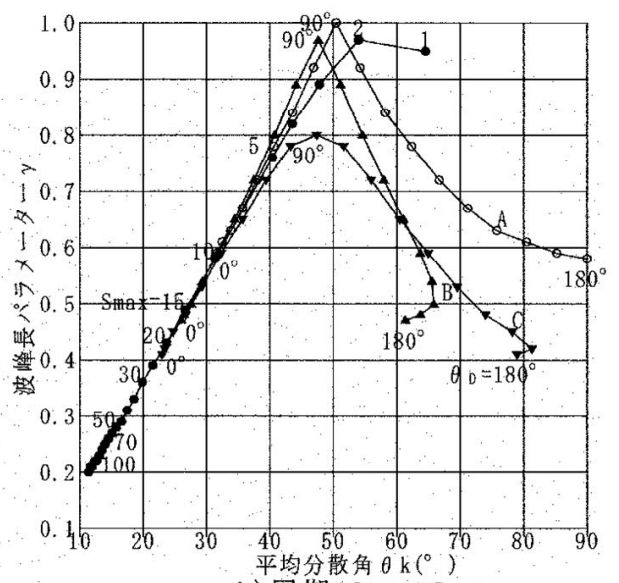

b) 周期 $10 \mathrm{~s} \sim 16 \mathrm{~s}$

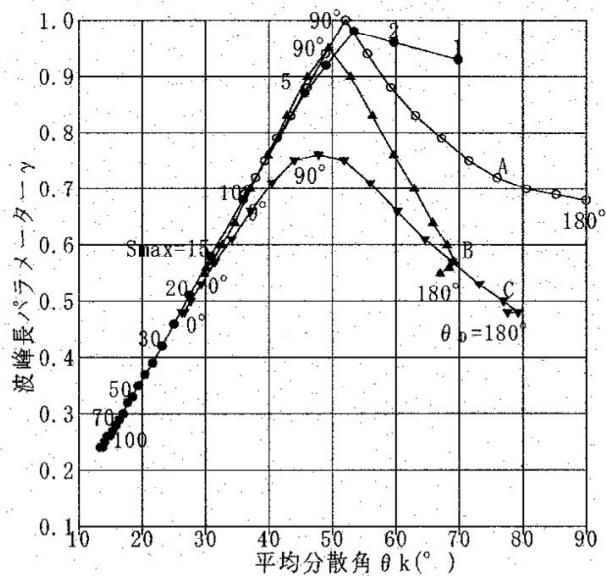

d) 周期 $6 \mathrm{~s} \sim 8 \mathrm{~s}$

図-7 $\theta_{\mathrm{k}}$ と $\gamma$ の関係(光易型方向分布関数) 
向きとして表現可能である境界を示す判断基準とし て取り扱える。

(3) いわゆる直記式波浪計に使われている，水平流 速・垂直位置を用いる共分散波向き計算にも応用で き，周期帯別共分散波向きも高速に計算できる.

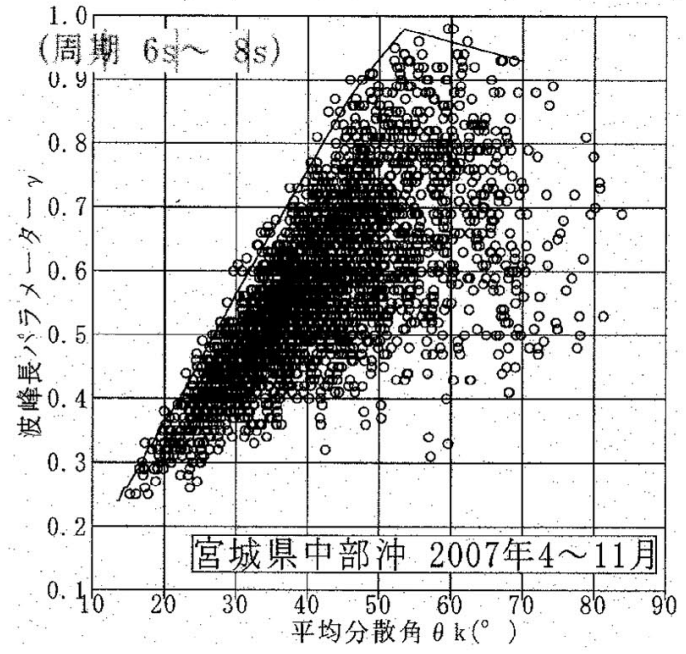

図-8 $\theta_{k}$ と $\gamma$ の関係 (観測結果 : $3.0 \mathrm{~m}>\mathrm{II}_{\mathrm{s}}>2.0 \mathrm{~m}$ )

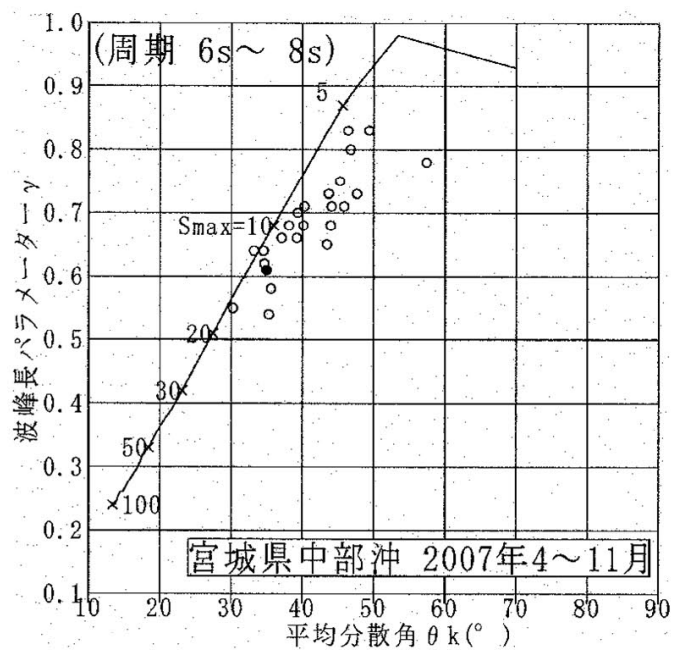

図-9 $\theta_{k}$ と $\gamma$ の関係（観測結果 : $\mathrm{H}_{\mathrm{s}}>6.0 \mathrm{~m}$ )
謝辞：本研究では，国土交通省東北地方整備局が設 置したGPSブイ式波浪計により観測されたデータを 活用させて頂いた。ここに感謝の意を表します.

\section{参考文献}

1) 清水勝義，永井紀彦，里見茂，李在昫，久高将信，藤 田孝:ブイ動摇特性を考慮した大水深波浪観測データ 処理システムの構築, 土木学会, 海岸工学論文集, 第 53巻, pp. 1406-1410, 2006.

2) 清水勝義, 永井紀彦, 橋本典明, 岩崎峯夫, 安立重昭, 奥勇一郎：GPSブイ式波浪計を対象とした複合的な波 向き計算手法の提案, 海洋開発論文集, 第 23 巻, pp. 231-236, 2007.

3) 合田良実:共分散法を用いた波向推定方式の数值的検討, 港研報告，第20巻 第3号, pp53-92，1981年9月。

4）小舟浩治,橋本典明,佐々木弘：野島沖海域の波浪特性, 土木学会, 海岸工学論文集, 第 32 巻, pp. 124-128, 1985. 